\title{
Genetic Variation for Biofortifying The Maize Grain
}

\author{
Gönül Cömertpay ${ }^{1}$ Faheem Shehzad Baloch², Halil Erdem³ \\ ${ }^{1}$ Eastern Mediterranean Agricultural Research Institute, 01330 Yureğir/Adana, Turkey. \\ ${ }^{2}$ Department of Field Crops, Faculty of Agricultural and Natural Science, Abant İzet Baysal University, 14280 Bolu, Turkey \\ ${ }^{3}$ Department of Soil Science and Plant Nutrition, Faculty of Agriculture, University of Gaziosmanpaşa 60240 Tokat, Turkey \\ A R T I C L E I N F O \\ A B S T R A C T \\ Article history: \\ Received 24 April 2016 \\ Accepted 23 June 2016 \\ Available online, ISSN: 2148-127X \\ Keywords: \\ Mineral variation \\ Landraces \\ Maize \\ Turkey

\begin{abstract}
The maize germplasm variation is valuable for breeders to develop elite hybrids with increased mineral contents in the maize grain to eliminate mineral malnutrition, which is referred as HIDEN HUNGER. Therefore, we aimed to determine mineral element diversity of maize landraces collected from different geographical regions of Turkey. There was huge diversity for all mineral traits and other quality traits. Turkish maize landraces showed high variation for $\mathrm{Zn}\left(17-41.34 \mathrm{mg} \mathrm{kg}_{-}{ }^{1}\right), \mathrm{Fe}\left(13.52-29.63 \mathrm{mg} \mathrm{kg}_{-}{ }^{1}\right), \mathrm{Cu}$ (0.77-3.34 mg kg- $\left.{ }^{1}\right), \mathrm{Mn}\left(5.68-14.78 \mathrm{mg} \mathrm{kg-}^{1}\right)$, Protein (6.6-11.6\%), starch content (73.3$80.0 \%$ ), oil content $(3.15-4.7 \%)$ and thousand grain weight $(177.0-374.9 \mathrm{~g})$. There were significant positive and negative associations among mineral elements and quality traits. The principal component analysis differentiated some maize landraces from the rest, and these diverse landraces could be used in the maize breeding program with biofortification purpose.
\end{abstract}

Quality

${ }^{*}$ Corresponding Author:

E-mail: balochfaheem13@gmail.com

\section{Introduction}

A sufficient and balanced diet is possibly the most important contribution to human health and also animal feed. Mineral and vitamin deficiencies combine together effect the most population of the world more than does the protein-energy malnutrition. Micronutrient deficiency is a widespread critical problem in many developing and least developed countries where people rely upon cerealbased diets that are inherently deficient in micronutrients (Bouis and Welch, 2010; Pfeiffer and Mc Clafferty, 2007). According to report published by world health organization (WHO, 2002)more than half of the world's population is afflicted by iron $(\mathrm{Fe})$ and zinc $(\mathrm{Zn})$ deficiencies, these ranking fifth and sixth among the ten most important risk causes of illness and disease in lowincome countries, it popularly phrased as "hidden hunger" (Khush et al., 2012; Stein, 2010). Micronutrients not only plays important role in the human's health but also for plant nutrition. Thus plant breeding hold a great promise for making major, low cost and sustainable contribution for reducing micronutrient malnutrition and may have important spin-off effects on increasing farm productivity of low income farmer communities in the developing world (Bouis, 2003).

Micronutrients play a critical role in cellular and humoral immune responses, cellular signaling and function, work capacity, reproductive health, learning and cognitive functions (Guerrant et al., 2000; Kapil and Bhavna, 2008). Since human body cannot synthesize micronutrients, they must be made available through diet (Baloch et al., 2014). Traditional interference to address mineral deficiencies have focused on supplementation, food fortification and dietary diversification. For various reasons, none of these have been universally successful. Among strategies for enhancing iron and zinc levels in cereal grains, plant breeding strategy (biofortification) appears to be the most sustainable and cost-effective approach (e.g. Cakmak, 2008; Graham et al., 1999; Welch and Graham, 2002).

The development of an effective breeding program to improve mineral content in maize depends on the presence of genetic variation. Exploring natural biodiversity as a source of novel alleles to improve the productivity, adaptation, quality, and nutritional value of crops is of prime importance in 21 st century breeding programs (Saha et al., 2009). Genetic variations have been reported in maize inbred lines, landraces and hybrids for all the mineral elements most frequently lacking in human diets. This can be used in breeding programs to increase mineral concentrations in maize grain (White and Broadley, 2005).

Maize is one of the most important crop in Turkish agriculture after wheat and barley (Comertpay et al., 
2012). It is extensively cultivated in Mediterranean $(29.1 \%)$ and Southeast Anatolia (29\%) regions and, followed by the Aegean (10.5\%) regions (TUIK, 2015)). According to the Statistical database of Food and Agricultural organization of the world (FAOSTAT, 2015), Turkey produces 6.4 million tons of maize grains per year from 688.169 ha of land (about $3.33 \%$ of areas under cultivation in Turkey. In Turkey, $64 \%$ of maize is used for forage purposes and $36 \%$ for food and industrial products (Ege and Karahocağil, 2001). Maize alone is responsible for providing $15 \%$ of the protein and $20 \%$ of the calories in the human diet, and this crop covered a cultivated area of 159.5 million hectares in 2009 (FAOSTAT, 2009). The importance of this crop is demonstrated by the multiple ways it is exploited (Messias et al., 2013). Cereal grain is a good and easily accessible source of $\mathrm{Fe}$ and $\mathrm{Zn}$ for both feed and food. Although maize grain is low in some micronutrients, humans and animals can obtain at least part of their nutritional requirements from maize grain (Mason and D'Croz-Mason, 2002). It was proved that there is sufficient genetic variation and workable heritability to improve $\mathrm{Fe}$ and $\mathrm{Zn}$ levels in maize (Graham et al., 1999; Bänziger and Long, 2000)

Maize landraces have long been of socio-economic importance for family farming systems in Turkey and are still cultivated throughout different regions of Turkey. Maize landraces are open-pollinated varieties (OPVs), and therefore they underwent long-term natural and artificial selection in the past centuries. A large number of maize landraces have arisen over time, selected for their adaptation to local environmental conditions by farmers. Natural diversity detected in the maize germplasm, provides an opportunity for incorporating higher levels of iron, zinc, and beta-carotene into these grains (Hoisington, 2002).
Very limited results have been published on the micronutrient contents of the maize grain. The natural genetic variation harbored by maize grain could be very important for biofortifying the maize grain for reducing the mineral malnutrition in the developing world. Therefore the objective of this study was to check the natural variation existed in the maize grain. We discussed here available genetic variation for $\mathrm{Fe}$ and $\mathrm{Zn}$, relationship among micronutrients and pattern of variation through multivariate analysis. We examined 79 Turkish maize landraces for 3 quality parameters and four microelements. This will open ways for starting the biofortification of maize grain in Turkey

\section{Material and Method}

As part of a biofortification studies in maize at Eastern Mediterranean Research institute, we are trying to develop maize hybrids having increased mineral concentrations. For crossing, we need to identify the natural germplasm having increased mineral concentrations. Therefore here our main aim was to identify the landraces having high concentration $\mathrm{Zn}, \mathrm{Fe}$ and other mineral elements. The research material consisted of 79 maize landraces collected from maize growing areas of various geographical provinces of Turkey. The seeds of the landraces were kindly obtained from Menemen gene bank of the Aegean Agricultural Research Institute, Izmir, Turkey. Identification numbers and collection locations are presented in Table 1. Field experiment was carried out in 2009 at the University of Çukurova, Adana $\left(37^{\circ} 00^{\prime} 56^{\prime \prime} \mathrm{N}, 35^{\circ} 21^{\prime} 29^{\prime \prime} \mathrm{E}\right)$, a location which experiences a typical Mediterranean climate of hot, dry summers

Table1 Origin, collection sites of 79 open pollinated Turkish maize populations used in this study

\begin{tabular}{|c|c|c|c|c|}
\hline No & Genbank Identification Number & Geographical Province & Collection Site & Kernel Type \\
\hline 1 & TR 51484 & Adana & Kozan, Gaziköy & Flint / Dent \\
\hline 2 & TR 51540 & Adapazarı & Karasu & Flint / Dent \\
\hline 3 & TR 37944 & Adiyaman1 & Kahta, Adalı vil. & Dent \\
\hline 4 & TR 37985 & Adiyaman2 & Samsat, Balcilar vil. & Dent \\
\hline 5 & TR 37998 & Afyon & Dinar & Flint / Dent \\
\hline 6 & TR 38147 & Ağr12 & Tutak, Yoğunhisar vil. & Flint / Dent \\
\hline 7 & TR 38150 & Amasya1 & Taşova & Flint / Dent \\
\hline 8 & TR 38201 & Amasya2 & Evince & Flint / Dent \\
\hline 9 & TR 38036 & Amasya3 & Göynücek & Flint / Dent \\
\hline 10 & TR 38039 & Artvin1 & Erhavi & Flint / Dent \\
\hline 11 & TR 38243 & Artvin2 & Borçka & Flint / Dent \\
\hline 12 & TR 38272 & Artvin3 & 4 Km E Orus, Şenköy vil. & Flint / Dent \\
\hline 13 & TR 37484 & Artvin4 & Şavşat & Flint / Dent \\
\hline 14 & TR 37490 & Aydın 1 & Bozdoğan, Kilavuzlar vil. & Flint / Dent \\
\hline 15 & TR 37499 & Aydin 2 & Sultanhisar, Uzunlar vil. & Flint / Dent \\
\hline 16 & TR 37500 & Balıkesir1 & Gönen, Tütüncüler vil. & Dent \\
\hline 17 & TR 38375 & Balıkesir2 & Manyas, Süleymanlı vil. & Flint / Dent \\
\hline 18 & TR 38411 & Balıkesir3 & Bigadiç, Kadıköy & Flint / Dent \\
\hline 19 & TR 38437 & Bolu & Düzce, Döngelli vil. & Flint / Dent \\
\hline 20 & TR 37543 & Burdur1 & Yeșilova & Flint / Dent \\
\hline
\end{tabular}




\begin{tabular}{|c|c|c|c|c|}
\hline 21 & TR 38471 & Burdur2 & Tefenni, Çaylıkköyü vil. & Flint / Dent \\
\hline 22 & TR 37605 & Bursal & Orhangazi, Çeltikli vil. & Flint / Dent \\
\hline 23 & TR 37630 & Bursa2 & Demirtaş vil. & Flint / Dent \\
\hline 24 & TR 37780 & Çanakkale & Çan & Flint / Dent \\
\hline 25 & TR 55545 & Çorum1 & Ortaköy & Flint / Dent \\
\hline 26 & TR 55463 & Çorum2 & Sungurlu & Flint / Dent \\
\hline 27 & TR 55469 & Denizli1 & Acıpayam, Gölcük vil. & Flint / Dent \\
\hline 28 & TR 49312 & Denizli2 & Kayhan vil. & Flint / Dent \\
\hline 29 & TR 57657 & Denizli3 & Tavas, Solmaz vil. & Dent \\
\hline 30 & TR 57661 & Diyarbakır & Çermik, Pamuklu vil. & Flint / Dent \\
\hline 31 & TR 44446 & Edirne1 & Havsa & Dent \\
\hline 32 & TR 44469 & Edirne2 & Karaağaç & Flint / Dent \\
\hline 33 & TR 44519 & Edirne 4 & Keşan & Dent \\
\hline 34 & TR 36977 & Erzurum1 & Horasan, Esence vil. & Flint / Dent \\
\hline 35 & TR 37006 & Erzurum2 & Tortum, Pehlivanlı vil. & Flint / Dent \\
\hline 36 & TR 37010 & Eskişehir1 & Sivrihisar & Flint / Dent \\
\hline 37 & TR 37013 & Eskişehir2 & Sivrihisar & Flint / Dent \\
\hline 38 & TR 37056 & Gaziantep1 & Nizip, Belkız, Kavunlu vil. & Flint / Dent \\
\hline 39 & TR 37105 & Gaziantep2 & Nizip,Aşağıçardaklı Fındıklı mezra & Flint / Dent \\
\hline 40 & TR 50558 & Giresun1 & $3 \mathrm{Km} \mathrm{S}$ Doğakent, Demirci vil. & Flint / Dent \\
\hline 41 & TR 50550 & Giresun2 & Barça vil. & Flint / Dent \\
\hline 42 & TR 50548 & Isparta1 & Keçiboru, Aydoğmuş vil. & Flint / Dent \\
\hline 43 & TR 50537 & Isparta2 & Keçiborlu, Gümüşgün vil. & Flint / Dent \\
\hline 44 & TR 50527 & İstanbul & Çatalca, Karaca köy vil. & Flint / Dent \\
\hline 45 & TR 50511 & İzmir1 & Bozdăg & Flint / Dent \\
\hline 46 & TR 50565 & İzmir2 & Torbalı, Karaot vil. & Dent \\
\hline 47 & TR 50563 & K.maraş1 & Andirın & Flint / Dent \\
\hline 48 & TR 50564 & K.maraş2 & Türkoğlu & Flint / Dent \\
\hline 49 & TR 50654 & Kars & Kötek & Flint / Dent \\
\hline 50 & TR 50667 & Kastamonu1 & Araç, Yeniceköy vil., Köseler mah. & Flint / Dent \\
\hline 51 & TR 50674 & Kastamonu2 & Emirler vil. & Flint / Dent \\
\hline 52 & TR 53245 & Kurklareli & Çakillı & Flint / Dent \\
\hline 53 & TR 50643 & Kocaeli & Kandıra, Akçaova & Flint / Dent \\
\hline 54 & TR 47889 & Konya & Beyşehir, Damlapınar vil. & Flint / Dent \\
\hline 55 & TR 39563 & Kütahya & Saphane, Gaipler vil. & Flint / Dent \\
\hline 56 & TR 54214 & Manisa & Yurtdağ 1 & Flint / Dent \\
\hline 57 & TR 54191 & Muğla1 & Köyceğiz, Beyobası vil. & Dent \\
\hline 58 & TR 54199 & Muğla2 & Köyceğiz, Beyobası vil. & Flint / Dent \\
\hline 59 & TR 48470 & Ordu & Mesudiye, Güzle vil. & Flint / Dent \\
\hline 60 & TR 48479 & Rize1 & Çayeli & Flint / Dent \\
\hline 61 & TR 50136 & Rize2 & $33 \mathrm{Km}$ S İkizdere yolu, İskender vil & Dent \\
\hline 62 & TR 50161 & Sakarya1 & Küçükhatatlı vil. & Flint / Dent \\
\hline 63 & TR 48452 & Sakarya2 & Adapazarı-Hendek, Kazımiye vil. & Flint / Dent \\
\hline 64 & TR 48454 & Samsun1 & Bafra, Altınkaya Dam & Flint / Dent \\
\hline 65 & TR 42703 & Samsun2 & 19 Mayıs, Karaköy vil. & Dent \\
\hline 66 & TR 42719 & Sinop & Gerze, Çalboğaz vil. & Flint / Dent \\
\hline 67 & TR 42725 & S.urfa & Hilvan, Uğra vil. & Dent \\
\hline 68 & TR 42750 & Tekirdağ 1 & Güngörmez & Flint / Dent \\
\hline 69 & TR 42803 & Tekirdağ 2 & Saray & Flint / Dent \\
\hline 70 & TR 42856 & Tokat1 & Resadiye, Soğukpınar vil. & Flint / Dent \\
\hline 71 & TR 42949 & Tokat2 & Niksar, Kuraç vil. & Flint / Dent \\
\hline 72 & TR 42958 & Trabzon1 & Tonya & Flint / Dent \\
\hline 73 & TR 42985 & Trabzon2 & 2 Km N Atatürk köşkü, Soğuksu vil. & Dent \\
\hline 74 & TR 42614 & Trabzon3 & Akyaz vil. & Flint / Dent \\
\hline 75 & TR 49202 & Trabzon4 & Akçaabat, Düzköy vil. & Flint / Dent \\
\hline 76 & TR 49214 & Ussak1 & Dumlupinar & Flint / Dent \\
\hline 77 & TR 49234 & Uşak2 & Banaz, Güllüçam vil. & Flint / Dent \\
\hline 78 & TR 49309 & Zongukdak1 & Ereğli & Flint / Dent \\
\hline 79 & TR 45513 & Zonguldak2 & Bartın & Flint / Dent \\
\hline
\end{tabular}




\section{Quality and Micronutrient Analysis}

Some amount of seed samples was taken from every landrace with 3 replications and seeds were bulked both for quality and micronutrient analysis. The quality parameters (protein, starch and oil content) were determined by using Fourier transform near infrared spectroscopy (FT-NIR). The micronutrient analysis was implemented following procedure. Seed samples $(0.4 \mathrm{~g})$ were digested in a closed microwave digestion system (MARSxpress, CEM Corp.) in $5 \mathrm{~mL}$ of concentrated $\mathrm{HNO} 3$ and $2 \mathrm{~mL}$ of concentrated $\mathrm{H} 2 \mathrm{O}$ and were then analyzed for mineral nutrients with an inductively coupled plasma optical emission spectrometer (ICP-OES; Vista-Pro Axial; Varian Pty Ltd., Australia).

\section{Statistical Analysis}

Standard one-way analysis of variance (ANOVA) was performed for each mineral element using JUMP statistical computer software program. Significant differences between accessions $(\mathrm{P} \leq 0.05)$ were detected for all studied mineral traits. Principal component analysis (PCA) based on 8 characters was used to identify the patterns of variation within the set of 79 landraces. The PCA was done using JMP statistical software. The eigenvalue-one criterion was used to retain the principal components that contributed considerable variability. Correlation among studied traits was calculated using the Pearson correlation using JUMP statistical computer software program.

\section{Results}

There were high variations for studied mineral traits in 79 maize landraces. Means of the all 79 landraces greatly varied for all 8 traits (Table 2). The mean, maximum, minimum, standard deviation of all traits all are given in the Table 3.

The mean protein content of all maize landraces was $8.7 \%$, and it ranged from $6.6 \%$ for landraces of Adana to
$11.6 \%$ for landraces of Diyarbakır. The highest protein content among Turkish maize landraces was approximately double from its minimum value. The mean oil content was 3.9 and varied between 3.15 and $4.8 \%$. In case of starch contents, the highest starch content was $80 \%$ in landrace of Adana and minimum starch content was $73.5 \%$ in landrace of Çanakkale and mean value was $78.3 \%$. For thousand grain weight, landrace of Adana showed minimum value of $177 \mathrm{~g}$ and landrace of K.Maraş1 showed highest value of 1000 grain weight of 368.7, this value was more than 2 fold than the minimum.

When we look at the variation of microelement content in Turkish germplasm, we can easily see that there was much variation among Turkish maize germplasm for mico-element contents in the maize grain. Zinc concentration in the maize grain varied two and half times between maximum and minimum values and It varied between $17.0-41.3 \mathrm{mg} \mathrm{kg}^{-1}$ with mean value of $26.0 \mathrm{mg} \mathrm{kg}^{-1}$. The highest $\mathrm{Zn}$ value was found in landrace of Balıkesir2 and minimum in the landrace of Diyarbakır. The maximum value of the iron content in the Turkish maize germplasm was fold higher than minimum value. The amount of iron in the grain of Turkish maize germplasm varied between 13.5-29.6 mg kg-1 with an average of $20.5 \mathrm{mg} \mathrm{kg}^{-1}$. Lowest Fe content was depicted in the Giresun1 and highest seen in Artvin1. In case of copper content, maximum value was 5 times more than the minimum value and it ranged from 0.77 to $3.84 \mathrm{mg}$ $\mathrm{kg}^{-1}$ with an average of $2.2 \mathrm{mg} \mathrm{kg}^{-1}$. Landraces of Mugla1 and Kastamonu2 showed highest and lowest copper contents respectively. When we see the variation of manganese content in the grain of maize, there was high variation in $\mathrm{Mn}$ content. The maximum value of $\mathrm{Mn}$ was 3 fold greater than the minimum value showing high diversity. The grain of maize landrace from Izmir harbored highest Mn content (14.7.2) and landrace of Trabzon3 with minimum Mn content (5.68) with a mean value of 10.0 .

Table 2 Maximum, minimum, mean and standard deviation values of mineral element contents and quality traits of 79 maize landraces

\begin{tabular}{l|cccc}
\hline \multicolumn{1}{c|}{ Traits } & Maximum & Minimum & Mean & Stdev \\
\hline TGW $(\mathrm{g})$ & 374.9 & 177.0 & 282.6 & \pm 44.8 \\
Protein $(\%)$ & 11.6 & 6.6 & 8.7 & \pm 0.98 \\
Oil $(\%)$ & 4.7 & 3.15 & 3.9 & \pm 0.26 \\
Starch (\%) & 80.0 & 73.3 & 76.3 & \pm 1.10 \\
Zn $\left(\mathrm{mg} \mathrm{kg}^{-1}\right)$ & 41.34 & 17.0 & 26.0 & \pm 4.80 \\
Fe $\left(\mathrm{mg} \mathrm{kg}^{-1}\right)$ & 29.63 & 13.52 & 20.5 & \pm 4.10 \\
$\mathrm{Cu}\left(\mathrm{mg} \mathrm{kg}^{-1}\right)$ & 3.84 & 0.77 & 2.2 & \pm 0.70 \\
$\mathrm{Mn}\left(\mathrm{mg} \mathrm{kg}^{-1}\right)$ & 14.78 & 5.68 & 10.0 & \pm 1.82 \\
\hline
\end{tabular}

Table 3 Correlation coefficients among different quality and mineral traits

\begin{tabular}{|c|c|c|c|c|c|c|c|}
\hline Traits & $\overline{T G W}$ & Protein & $\overline{\text { Oil }}$ & Starch & $\overline{\mathrm{Zn}}$ & $\overline{\mathrm{Fe}}$ & $\overline{\mathrm{Cu}}$ \\
\hline Protein & 0.249 & - & & & & & \\
\hline Oil & $0.385^{*}$ & $-0.482^{* *}$ & - & & & & \\
\hline Starch & -0.170 & $-0.553^{* *}$ & 0.199 & - & & & \\
\hline $\mathrm{Zn}$ & $-0.343^{* *}$ & 0.123 & $0.285^{*}$ & -0.150 & 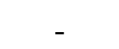 & & \\
\hline $\mathrm{Fe}$ & $-0.405^{* *}$ & 0.095 & $0.278^{*}$ & -0.157 & $0.488^{* *}$ & - & \\
\hline $\mathrm{Cu}$ & -0.147 & 0.060 & 0.156 & -0.163 & $0.428^{* *}$ & $0.244^{*}$ & - \\
\hline Mn & $-0.302^{* *}$ & 0.005 & $0.326^{* *}$ & -0.105 & $0.482^{\text {** }}$ & $0.470^{* *}$ & $0.362^{* *}$ \\
\hline
\end{tabular}


Table 5 Eigenvectors, eigenvalues, individual and cumulative percentages of variation explained by the first six principal components (PC) after assessing quality and mineral nutrient traits in 79 Turkish maize landraces

\begin{tabular}{|c|c|c|c|c|c|c|}
\hline \multirow{2}{*}{ Variables } & \multicolumn{6}{|c|}{ Eigen vectors } \\
\hline & PC1 & $\mathrm{PC} 2$ & PC3 & PC4 & PC5 & PC6 \\
\hline TGW (g) & -0.38396 & 0.23183 & 0.41648 & 0.46887 & 0.38048 & 0.36483 \\
\hline Protein $(\%)$ & -0.07357 & 0.62379 & -0.20089 & -0.14362 & 0.07421 & 0.11143 \\
\hline Oil (\%) & 0.35903 & -0.36960 & 0.09094 & 0.57630 & -0.31839 & 0.21533 \\
\hline Starch (\%) & -0.03520 & -0.57021 & 0.06649 & -0.45243 & 0.51635 & 0.21524 \\
\hline $\mathrm{Zn}\left(\mathrm{mg} \mathrm{kg}^{-1}\right)$ & 0.45974 & 0.17813 & 0.05715 & -0.19149 & 0.03739 & 0.73652 \\
\hline $\mathrm{Fe}\left(\mathrm{mg} \mathrm{kg}^{-1}\right)$ & 0.44035 & 0.13574 & -0.44483 & 0.03240 & 0.09804 & -0.00093 \\
\hline $\mathrm{Cu}\left(\mathrm{mg} \mathrm{kg}^{-1}\right)$ & 0.33202 & 0.19022 & 0.75262 & -0.32284 & -0.20958 & -0.23206 \\
\hline $\operatorname{Mn}\left(\mathrm{mg} \mathrm{kg}^{-1}\right)$ & 0.44889 & 0.09513 & 0.07696 & 0.28422 & 0.65330 & -0.40678 \\
\hline Eigenvalue & 2.7482 & 1.9593 & 0.8322 & 0.6449 & 0.5652 & 0.4863 \\
\hline Percent & 34.353 & 24.491 & 10.402 & 8.061 & 7.065 & 6.079 \\
\hline Cum Percent & 34.353 & 58.843 & 69.246 & 77.306 & 84.372 & 90.450 \\
\hline
\end{tabular}

Correlation for 3 quality and 4 mineral trait parameters are shown in the Table 3. There were significant and positive correlations among the contents of different mineral elements. Thousand grain weight has significant but negative correlation with all mineral traits (Zn, r=0.343; $\mathrm{P}<0.01 ; \mathrm{Fe}, \mathrm{r}=0.405 ; \mathrm{P}<0.01 ; \mathrm{Mn}, \mathrm{r}=0.302$; $\mathrm{P}<0.01)$ except copper content. Oil content possessed significant and positive correlation with contents of $\mathrm{Zn}$ $(\mathrm{r}=0.285 ; \mathrm{P}<0.05), \quad \mathrm{Fe} \quad(\mathrm{r}=0.278 ; \mathrm{P}<0.05)$ and $\mathrm{Mn}$ $(\mathrm{r}=0.326 ; \mathrm{P}<0.01)$ except $\mathrm{Cu}$ content. Oil content has also significant and negative correlation with protein content $(\mathrm{r}=0.482 ; \mathrm{P}<0.01)$ and also significant positive correlation with thousand kernel weight $(\mathrm{r}=0.385 ; \mathrm{P}<0.05)$. Starch content of the grain did not harbour any association with other traits except protein content $(\mathrm{r}=0.553 ; \mathrm{P}<0.01)$. Most of the mineral contents harboured significant and positive relationships with each other; however, the large number of observations increased the test power, resulting in significance for most of the correlations. Hence, only values of 0.5 or above are discussed. When we observe the correlation pattern of micro elements with each other and with quality traits, it was noted that $\mathrm{Zn}$ and other mineral element contents have significant and positive correlations with each other. $\mathrm{Cu}$ content did not have any correlation with all three quality traits.

Finally, PCA, based on 3 qualities, and contents of 4 minerals was used to assess the patterns of diversity within a set of 79 Turkish maize landraces. Using PCA based on the correlation matrix, we calculated eigenvalues, percentages of variation, and load coefficients of the first 5 components for all traits (Table 4). PCA yielded six principal components (PC1, PC2, PC3, PC4, PC5, PC6), explaining 90,450\% of total variance in data. First principal component was the most component of variation explaining $34.35 \%$ of the total variation. The contents of three mineral elements were the main treasure of variation. $\mathrm{Zn}$ content explained $45.9 \%$ of the total variation exhibited followed by $\mathrm{Mn}$ and $\mathrm{Fe}$ contents explaining around $44 \%$ of the total variation. Quality traits did get any place in the PC1 and get identity in PC2. The second principal component (PC2) accounted for $58.84 \%$ of the variability and was highly dependent on protein and starch contents. In PC2, Protein content was the main partner of the variation explaining $62 \%$ of the total variation of 79 Turkish landraces. Similarly starch content explained $57 \%$ of the total variations in PC2. Oil contents played important role in principle component four and explained $57 \%$ of the total variations. First two principle components were very important and explained more than half of the total variations hence, they were plotted graphically to demonstrate the relationship among Turkish maize germplasm collection (Figure 2).

\section{Discussions}

Biofortification is the development of micro nutrient dense crop varieties through conventional plant breeding. The main aim of the Harvest Plus is to reduce micronutrient malnutrition among poor populations in Africa, Asia, and Latin America, thereby improving food security and enhancing the quality of life. Harvest Plus currently focuses on three micronutrients that are recognized by the World Health Organization (WHO) as limiting: $\mathrm{Fe}, \mathrm{Zn}$, and provitamin $\mathrm{A}$, but other nutrients may be added in the future.

In defining breeding strategies and target levels of micronutrient enhancement, it is important to look beyond the total amount of micronutrients present in the grain. Breeding strategies must aim to generate micronutrientenhanced maize cultivars without compromising tolerance to abiotic and biotic stress, crop productivity, and acceptable end-use quality, thereby increasing the likelihood that farmers will adopt the cultivars and consumers will accept foods made from them.

To fully and effectively utilize the genetic variability of the Turkish maize germplasm for the enrichment of maize seeds with bioavailable mineral elements, it is necessary to study and evaluate the variations for mineral traits of maize germplasms from different origins and to identify germplasm groups from which elite inbred lines with high mineral elements could be created (Cakmak, 2008).

The current study presents a comprehensive analysis of quality traits (protein, oil, starch content) and micronutrient $(\mathrm{Zn}, \mathrm{Fe}, \mathrm{Cu}$, and $\mathrm{Mn}$ ) concentrations for a large germplasm collection. There was impressive 
variation among Turkish maize landraces for contents of micro-elements and quality traits. For example, $\mathrm{Zn}$ and Fe contents showed high and impressive variation in grain of Maize which could be used in developing hybrids for biofortification purpose. Similarly landraces showing higher 1000 grain weight also possess high micro nutrient contents illustrating that $\mathrm{Zn}$ and $\mathrm{Fe}$ fortified grain might also possessed high grain yield. Therefore Turkish maize landraces could be used in breeding program with specific objectives.

Quality protein maize (QPM) genotype reported to have higher concentration of $\mathrm{Fe}$ and $\mathrm{Zn}$ provides opportunity to develop multi nutrient rich maize through a systematic breeding approach.

Correlations among different traits are generally due to the presence of linked genes and the epistatic effect of different genes. Environment plays an important role in correlations. In some cases, environment affects both the traits simultaneously in the same direction or sometimes in different directions (Yücel et al., 2009). Several studies have reported significant positive correlation between $\mathrm{Fe}$ and $\mathrm{Zn}$ contents in maize and other crops (Baxter et al., 2013; Chakraborti et al., 2009; Lungaho et al., 2011; Baloch et al., 2014). This could be possibly due to linkage between the genes affecting the accumulations or pleotropic effects of the genes governing the accumulation of micronutrients and the existence of one or more common genetic-physiological mechanisms involved in mineral absorption or uptake by the root system, translocation and redistribution within the plant tissues, remobilization to the grain, or accumulation in the developing grain (Çakmak, 2008; Peleg et al., 2008; Chatvaz et al., 2010). Positive correlation was observed between kernel Fe and Znc contents by Qin et al. (2012), and it might be due to the colocalization of QTLs for both the traits which was also reported in the review of Gupta et al., (2015), there by suggesting the feasibility of simultaneous improvement of the both. Negative correlation of protein content with starch and oil contents showed that which trait should be selected in the breeding program. From the results of the correlation analysis, it could be concluded that selection for right character is also important because of correlation among different traits. For example $\mathrm{Zn}$ content has positive and significant correlation with the contents of other three micronutrients. Similarly thousand grain weight is one of the most important traits determining the final yield. Therefore the quality and yield of maize kernel can be improved by selecting parents with either higher $\mathrm{Zn}$ concentration or higher grain weight. However, results require careful verification by testing the germplasm under different agro-climatic conditions.

Multivariate analyses were utilized to measure the variation in germplasm collections and to evaluate the relative contributions that various traits add to the total variability in a crop germplasm collection. These analyses permit germplasm entries to be classified into groups with similar traits (Baloch et al., 2014; Karaköy et al., 2014). To analyse the structure of the genetic diversity among a set of 79 Turkish maize landraces, we performed PCA based on mean values. First two principle components were most important explaining more than half of the total variation harboured by the Turkish maize landraces. Contnets of $\mathrm{Zn}, \mathrm{Fe}, \mathrm{Mn}$, protein and starch were the traits responsible for this variation. Graph drawn by first two principle component (Figure 3) showed that some landraces were differentiated from the rest of the landraces. For example, landraces 17, 1069 and 47 were collected from Balikesir2, Artvin1, Tekirdag2 and K.Maras1possessed high Zn, Fe, Mn contents and TGW respectively. Similarly from PCA, many other landraces could be selected based on their diversity and could be used as parents in pre-breeding programs. One plant from each landraces should be selfed to produce inbred lines and future research should be focused on association mapping of the mineral elements by using these selfed genotypes. This will help to identify the locus responsible for increased mineral element in the faba bean, which will also help to develop the maize hybrids with increased mineral elements.
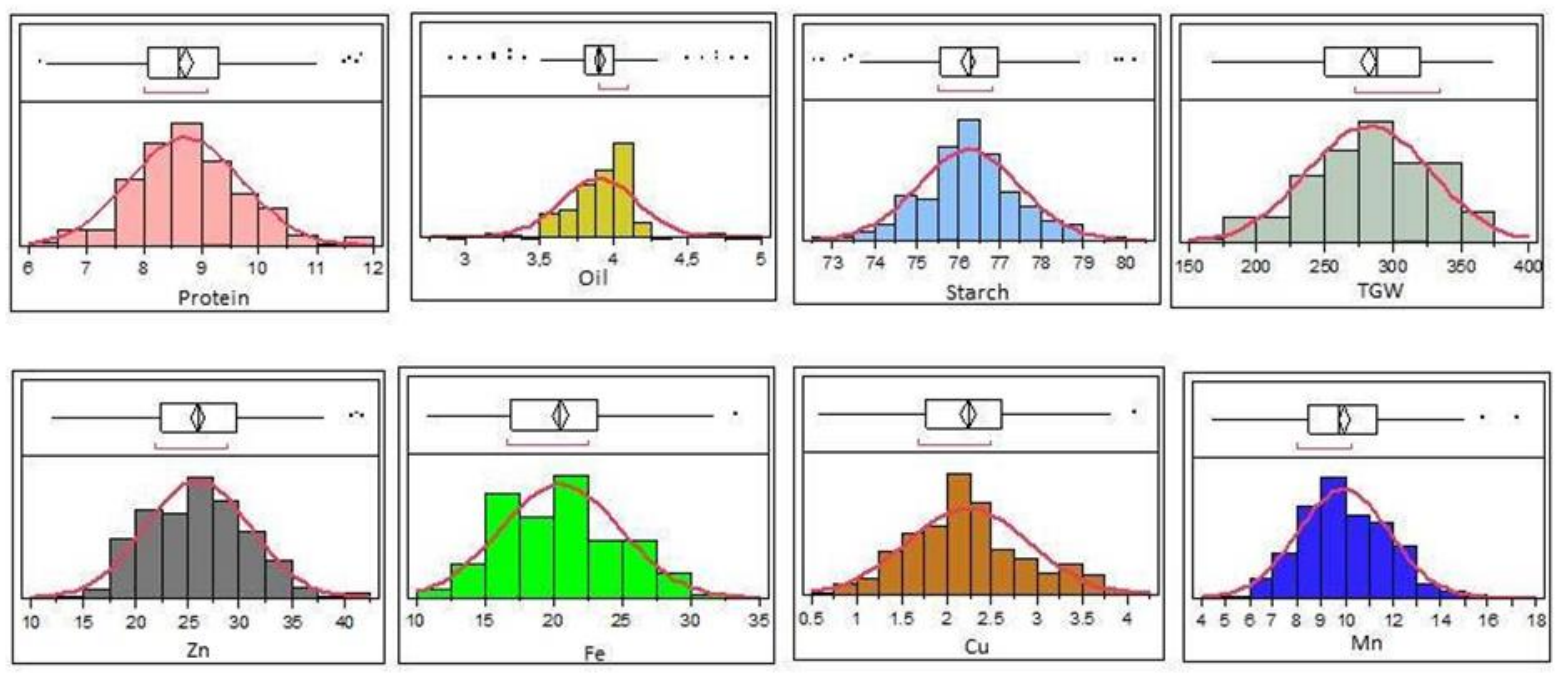

Figure 1 Frequency distribution of different quality and mineral traits in maize landraces 


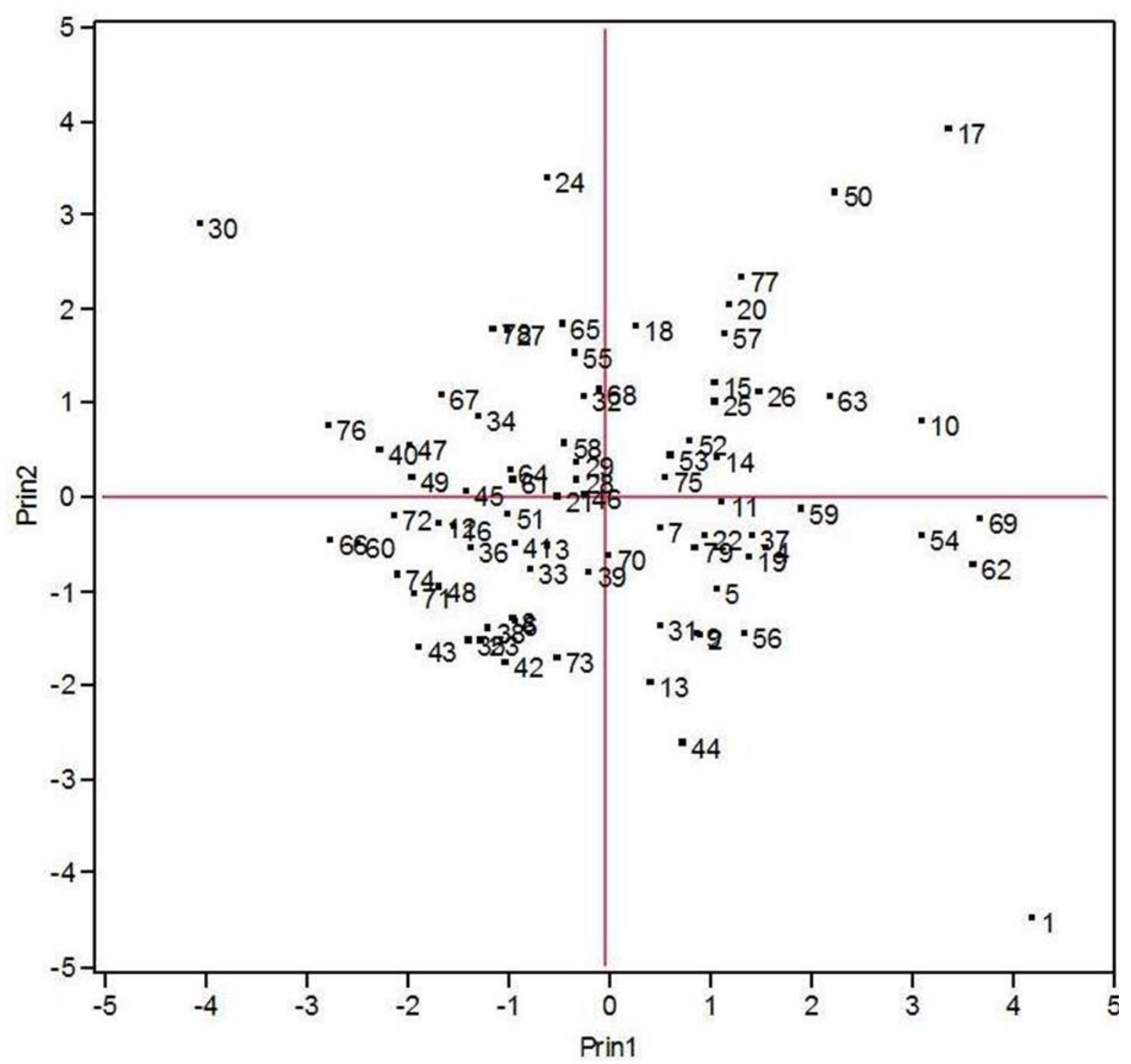

Figure 2 Principal component analysis of Turkish maize landraces for mineral and quality traits

In our previous study, we performed morphological characterization of Turkish maize landraces for nineteen agro-morphological traits (Comertpay et al., 2012) and genotypic diversity using SSR markers. Comertpay et al. (2012), also observed that Turkish maize landraces harbored high phenotypic and genotypic diversity. Identification of genetic variation is essential for achieving improvements in the mineral content of crops. Such variation can also be used to identify quantitative trait loci associated with mineral uptake and transport. Further detailed investigations by conducting field trials at multiple locations to verify the results and to study genotype $\mathrm{x}$ environment interactions and precautions should be done to study the mineral contents in selfed maize inbred lines. These landraces and associated information are useful to researchers and breeders from all over the world who are interested in biofortifying the maize grain. A promising genotype with stable trait expression can effectively be utilized as common donor or directly used as parent in the crossing program, across environments. Maintaining locally well adapted landraces would be an asset for our future and may contribute to Turkish maize breeding programs as well as other breeders worldwide interested in Turkish maize genetic resource.

\section{References}

Baloch FS, Karaköy T, Demirbaş A, Toklu F, Özkan H, Hatipoğlu R. 2014. Variation of some seed mineral contents in open pollinated faba bean (Vicia faba L.) landraces from Turkey. Turk J Agric For 38: 591-601.

Bänziger, M, Long J. 2000. The potential for increasing the iron and zinc density of maize through plant breeding. Food and Nutrition Bulletin 20:397-400.

Baxter IR, Gustin JL, Settles AM, Hoekenga OA. 2013. Ionomic characterization of maize kernels in the intermated B73 $\times$ Mo17 population, Crop Sci., 53: 208-220 http://dx.doi.org /10.2135/cropsci2012.02.0135

Bouis HE, Welch RM. 2010. Biofortification-A Sustainable Agricultural Strategy for Reducing Micronutrient Malnutrition in the Global South Crop Science 50:1, 20-32 doi:10.2135/cropsci2009.09.0531. 
Bouis HE. 2003. Micronutrient fortification of plants through plant breeding: can it improve nutrition in man at low cost? Proc. Nutr. Soc. 62: 403-411.

Çakmak I. 2008. Enrichment of cereal grains with zinc: Agronomic or genetic biofortification? Plant and soil, 302:1, pp 1-17. 10.1007/s11104-007-9466-3.

Chakraborti M. Prasanna BM, Hossain F, Singh AM, Guleria SK. 2009. Genetic evaluation of kernel Fe and $\mathrm{Zn}$ concentrations and yield performance of selected maize (Zea mays L.) genotypes, Range Mgmt. and Agroforestry, 30: 109-114.

Chatzav M, Peleg Z, Özturk L, Yazici A, Fahima T, Cakmak I, Saranga Y. 2010. Genetic diversity for grain nutrients in wild emmer wheat: potential for wheat improvement. Ann Bot 105: $1211-1220$.

Cömertpay G, Baloch FS, Kilian B, Ülger AC, Özkan H. 2012. Diversity assessment of Turkish maize landraces based on fluorescent labelled SSR markers. Plant Mol Biol Rep 30: 261274.

Ege H, Karahocağil P. 2001. Yemlik Tahıllar Arpa, Mısır durum ve tahmin 2001/2002 TEAE Yayını No 82, Ankara.

FAOSTAT. 2009. Food And Agriculture Organization of the United Nations. http://www.faostat.fao.org.

FAOSTAT. 2015 Food And Agriculture Organization of the United Nations. http://www.faostat.fao.org

Graham RD, Senadhira D, Beebe S, Iglesias C, Monasterio I. 1999. Breeding for micronutrient density in edible portions of staple food crops: conventional approaches. Field Crops Res 60: $57-$ 80.

Guerrant RL, Lima AA, Davidson F. 2000. Micronutrients and infection: interactions and implications with enteric and other infections and future priorities. J Infect Dis 182, S134-S138.

Gupta HS, Hossain F, Nepolean T, Vignesh M, Mallikarjuna MG. 2015. Understanding genetic and molecular bases of Fe and $\mathrm{Zn}$ accumulation towards development of micronutrient enriched maize, In: Nutrient Use Efficiency: From Basics to Advances, Rakshit A., Singh H.B., Sen A., (eds.), Springer Publications, pp. 255-282, doi. 10.1007/978-81-322-2169-2-17

Hoisington D. 2002. Opportunities for nutritionally enhanced maize and wheat varieties to combat protein and micronutrient malnutrition. Food Nutr Bull. 23(4):376-777.

Kapil U, Bhavna A. 2008. Adverse effects of poor micronutrient status during childhood and adolescence. Nutr Rev;60:S84-S90.

Karaköy T, Baloch FS, Toklu F, Özkan H. 2014. Variation for selected morphological and quality-related traits among 178 faba bean landraces collected from Turkey. Plant Genetic Resources: Characterization and Utilization 12: 5-13.
Karaköy T, Erdem H, Baloch FS, Toklu F, Eker S, Kilian B, Özkan H. 2012. Diversity of macro-and micronutrients in the seeds of lentil landraces. The Scientific World Journal, 2012: 1-9. doi: $10.1100 / 2012 / 710412$

Khush G, Lee S, Cho JI, Jeon JS. 2012. Biofortification of crops for reducing malnutrition. Plant Biotechnol Rep 6:195-202

Lungaho MG, Mwaniki AM, Szalma SJ, Hart J, Rutzke MA, Kochian LV, Glahn R, and Hoekenga OA. 2011. Genetic and physiological analysis of iron biofortification in maize kernels, PLOS One, 6: e20429 http://dx.doi.org/10.1371 /journal.pone.0020429

Mason SC, D'Croz-Mason NE. 2002. Agronomic practices influence maize grain quality. Journal of Crop Production. Vol. 5: 75-91

Messias, RS, Galli, V, Silva, SDA, Schirmer, MA, Rombaldi, CV. 2013. Micronutrient and functional compounds biofortification of maize grains. Critical Reviews in Food Science and Nutrition, in Press. http://dx.doi.org/10.1080/10408398. 2011.649314

Peleg Z, Saranga Y, Yazici A, Fahima T, Özturk L, Çakmak I. 2008. Grain zinc, iron and protein concentrations and zincefficiency in wild emmer wheat under contrasting irrigation regimes. Plant Soil 306: 57-67.

Pfeiffer WH, McClafferty B. 2007. HarvestPlus: breeding crops for better nutrition. Crop Sci 47:S88-S105

Qin H, Cai Y, Liu Z, Wang G, Wang J, Guo Y, Wang H. 2012. Identification of QTL for zinc and iron concentration in maize kernel and cob. Euphytica 187(3):345-358

Saha S, Singh G, Mahajan V, Gupta HS 2009. Variability of nutritional and cooking quality in bean (Phaseolus vulgaris L) as a function of genotype. Plant Foods Hum Nutr 64: 174-180.

Stein AJ, 2010. Global impacts of human malnutrition. Plant Soil 335: $133-154$

TUIK. 2015. Turkiye İstatistik kurumu. (https://biruni.tuik.gov.tr/ bitkiselapp /bitkisel.zul)

Welch RM, Graham RD. 2002. Breeding crops for enhanced micronutrient content. Plant Soil 245: 205-214.

White PJ, Broadley MR. 2005. Biofortifying crops with essential mineral elements. Trends Plant Sci 10: 586-593.

World Health Organization. 2002. The World Health Report. Reducing Risks, Promoting Healthy Life (World Health Organization, Geneva).

Yücel C, Baloch FS, Ozkan H. 2009. Genetic analysis of some physical properties of bread wheat grain (Triticum aestivum L. em Thell). Turk J Agric For 33: 525-535. 